\title{
Theoretical Framework for a Local, Agile Supply Chain to Create Innovative Product Closer to End-user: Onshore-Offshore Debate
}

\author{
Andrea Gyarmathy \\ Glasgow School for Business and Society at Glasgow Caledonian University, \\ Cowcaddens Rd, Glasgow G4 0BA UK \\ E-mail: andrea.gyarmathy@gcu.ac.uk (Corresponding Author) \\ Konrad Peszynski \\ School of Business IT and Logistics, \\ RMIT University, GPO Box 2476V, Melbourne, Victoria, Australia \\ E-mail: konrad.peszynski@rmit.edu.au \\ Leslie Young \\ School of Business IT and Logistics, \\ RMIT University, GPO Box 2476V, Melbourne, Victoria, Australia \\ E-mail: leslie.young@rmit.edu.au
}

\begin{abstract}
This paper presents a conceptual model of a viable onshore, agile supply chain approach for innovative product manufacturers in the manufacturing sector. As such, this paper provides insight into the drawbacks of offshore manufacturing and an empirical investigation into the importance of the manufacturing sector. This study aims to answer the research question: how can agile supply chain management add value to the manufacturing to create innovative products closer to the end-user? A theoretical framework was developed through a qualitative methodology to demonstrate effective onshore operation and supply chain. For the first time, the combination of Dynamic Capabilities (DC) and Total Cost of Ownership (TCO) theories has been used as a lens to examine the location decision of a close geographical supply chain network - global supply chain debate. Offshore manufacturing and global sourcing do not appear to fit the DC theory in a geographically and culturally distant situation, especially when supply chains involve operations in different continents. The 'theoretical perspective', including DC and TCO suggests that companies should frequently integrate, build and reconfigure internal and external competences to promptly react to the changing environment and they should also wisely calculate all the indirect, hidden, lifecycle and transaction costs of an operation when considering moving production offshore. Although studies in the agile supply chain area have examined competitiveness from several perspectives, there has been little to no research focusing on the advantages of agile, nearshore operation and supply chain solutions. This research notably widens the theoretical perspective of agility and adaptability for innovative product manufacturers in the manufacturing sector, and the viability of remaining close to the market and apply agile supply chain.
\end{abstract}

Keywords: agile supply chain, onshore, nearshore, backshore, operation, supply chain, strategic flexibility, manufacturing, dynamic capabilities, total cost of ownership

\section{INTRODUCTION}

This paper seeks to explore whether there is any particular type of manufacturer that can stay close to the enduser and whether agile supply chains add value to those manufacturers that decide to apply a 'close distance' supply chain. Furthermore, this study explores how agile supply chain management assists in creating value-added innovative products closer to end-users. Nowadays, manufacturing firms have recognised the fundamental advantage of supply chain management, however business are still struggling to achieve competitive advantage. In terms of the onshore operation and local supply chain debate a search of recent topics in supply chain management identified that Australian manufacturers are going against the American and European reshoring trend (Saccani, et al. 2017, Stanczyk et al. 2017, Vos et al. 2016, Arika 2013). The literature indicates a strong connection between reshoring decisions and the combination of responsive production and successful supply chain activities (Fine 2013, Tarafdar 2013, Malakouti et al. 2017). While focusing on the reshoring trend and reviewing academic literature, the following question emerged: How can agile supply chains add value to create innovative products closer to the end-user?

During the last two decades, outsourcing or offshore manufacturing has become the favoured management orientation (Butner 2010, Kotabe and Murray 2004, Mangan and Lalwani 2016, Masson et al. 2007, Oshri et al. 2009, Spina et al. 2013). Many companies believe that sourcing goods from low-labour-category countries - such as China, South Korea, Indonesia, Malaysia and India - is still viable (Christopher et al. 2011, Manyika et al. 2012, Oshri et al. 2009). While offshoring is a good strategy for lowering costs and prices for the end customer, there are inefficiencies created by the shift away from local sourcing, such as less 
flexibility and a slower response to changing customer demands (Fel \& Griette 2017, Foerstl et al. 2016, Holweg et al. 2011). A recent trend in Europe and the United States (US) is to stop outsourcing and return to local sourcing and onshore, nearshore manufacturing (Fratocchi et al. 2016, Sarder et al. 2014, Wiesmann et al. 2017).

After reviewing similar studies and publications in published journals about supply chain management, management strategies, manufacturing, operations and outsourcing, an increasing number of publications were found concerning the debate around the re-shoring and backshoring phenomenon around the world, which is an interesting and contrasting topic in an era when increasing numbers of manufacturers are deciding to move production to low-cost countries. Organisations must cautiously consider all the risks and costs of offshore manufacturing before deciding to send jobs offshore (Pagani 2004, Stanczyk et al. 2017). Although, in many cases, firms achieve benefits from global sourcing, they can also lose flexibility and commercial benefit (Butner 2010, Candace et al. 2011, Vos et al. 2016).

This paper not only provides an exploratory foundation for future research on the subject of agile supply chains, but also reveals the development of a conceptual model in a particular situational context. From an academic standpoint, this paper represents one of the initial empirical studies to focus on agile supply chain management alongside onshore manufacturing.

In particular, this paper explores how companies develop their operation and supply chain strategies; explains which factors affect the mechanisms that companies use to develop their supply chain management; and discusses which outcomes can be expected from companies who apply onshore operations with agile supply chain management. The objective of this paper is to determine whether there is any particular type of manufacturer that can apply nearshore or onshore operations and whether agile supply chains add value to manufacturers that decide to stay onshore. This research explores the viability of a theoretical framework for onshore strategic agility when making decisions about onshore or offshore manufacturers. Furthermore, this paper explores the viability of a theoretical framework for local strategic agility when making decisions about onshore or offshore operation and proximate supply chain in a manufacturing context. In the following sections, after summarising the literature review, including the different views and costs of offshore and onshore manufacturing, the theoretical background and the conceptual framework will be presented. In the discussion, the supplementary engagement of the two chosen theories is described. Finally, the practical and theoretical contribution of the study, as well as the limitation and future research, is discussed in the conclusion.

\section{LITERATURE REVIEW}

After reviewing similar studies and publications in various high-quality journals about supply chain management, management strategies, manufacturing, operations and outsourcing, an increasing number of articles were found concerning the phenomenon of reshoring and back-shoring operations, and local supply chains. When considering manufacturing in Australia, over the last two decades, an increasing number of mass-manufacturers have moved steadily to Asia mainly due to cost saving purposes. However, for managers of global supply chains, the question now is whether to consider scaling back offshore production by returning operations to be closer to the end-user avoiding the difficulties of a complex global or distant supply chain.

This paper determines whether there is any particular type of manufacturer that can stay local and whether agile supply chains add value to those manufacturers that decide to stay onshore. Agility has been applied to production, operation and supply chain practices since organisations realised its necessity to achieve major changes, serve customer demand efficiently, cooperate to increase competitiveness and utilise the impact of industrial knowledge and information (Goldman et al. 1995). However, considering the different types of products, some products are well suited to agile supply chains; whereas others may not be as suitable. Furthermore, regarding product types and implementing the appropriate supply chain, high-volume and low-demand uncertainty products should be matched with efficient processes and lean supply, whereas low-volume and high-uncertainty products should be matched with flexible processes and agile supply chains. (Stavrulaki and Davis, 2010, Galankashi \& Helmi, 2016).

It is vital to understand the difference between functional and innovative products to be able to identify the required supply chain solution. Functional products are standardised products that usually satisfy a basic human need. They do not change much over time; have a long lifecycle; and have stable, predictable demand (Frochlich \& Westbrook 2001, Lambert \& Cooper 2000; Simchi-Levi 2005). The production strategy for functional products is usually 'make-to-stock', with the lead time required for producing made-to-order products varying from six months to one year. The product lifecycle is more than two years and demand are usually predictable.

Innovative products are usually complex products with many variations in the finished product. The production strategy is 'make-to-order', the production lifecycle is three months to one year, the lead time required to produce madeto-order products is one day to two weeks, and demand is usually unpredictable (Chopra \& Meindl 2007, Simchi-Levi 2005). Although innovative products ensure companies will achieve a higher profit margin than with functional products, innovative product demand is usually unpredictable. Furthermore, for the purpose of sustaining a competitive advantage, companies are forced to introduce a continuous stream of new innovation. The short lifecycle and large variety of these products further increases unpredictability (Fisher 1997, Lo \& Power 2010). As Fisher (1997) further discussed, companies with innovative products can obtain greater reward by investing in high responsiveness in processes throughout the supply chain than by improving efficiency. Responsive supply chains mean they respond quickly to unpredictable demand; deploy buffer stock in parts and finished goods; invest aggressively in reducing lead time; use modular design to postpone product differentiation for as long as possible; and prefer speed, agility and quality throughout the entire supply chain (Lambert \& Cooper 2000, Lee et al. 1997, Porter 2008). 
Liao et al. (2010) argued that the higher the degree of agility applied to the supply chain, the more successfully it can adapt to changes in the market. Furthermore, Christopher (2000), Guansekaran et al. (2008) and Yusuf et al. (2004) argued that agility is the foundation on which to build the ability of the supply chain to respond more rapidly to changes in demand, which also improves supply chain responsiveness. Tarafdar (2013) stated that supply chain responsiveness is increased by the presence of an agile supply chain strategy, and supply chain responsiveness is positively associated with a firm's high performance. Moreover, agile supply chains allow firms to respond quickly to short-term changes in volatile markets and handle uncertainty in the market (Malakouti et al. 2017).

Initially, global sourcing was used for 'in-house' operations, such as supplying production with materials or goods from overseas (Holweg et al. 2011, Oshri et al. 2009). Recently, offshore manufacturing has become the favoured management orientation (Butner 2010). This direction seems to be effective and offers organisations the possibility to achieve competitive advantage. However, in the last ten years, global economic uncertainty and volatility have weakened the benefits of global sourcing as greater risks appear. Although locally manufactured goods cost slightly more than their imported counterparts, they are closer in terms of transportation, can potentially provide better quality and arrive on time (Gray et al. 2011, Stanczyk et al. 2017). Table 1 describes the costs of offshore operation/global sourcing, categorised as direct, dynamic and hidden types of expenses (Christopher et al. 2011, Hannon 2009, Holweg et al. 2011). Direct costs can be calculated because their variables are predictable; however, dynamic and hidden costs are mostly unpredictable. Thus, organisations are unable to express these costs in the business plan. To consider all the risks and costs of offshore manufacturing, organisations should make cautious decisions before choosing to send jobs offshore.

Table 1 Different costs of global sourcing and offshore manufacturing (Adopted from Christopher et al. 2011; Hannon 2009; Holweg et al. 2011)

\begin{tabular}{|c|c|c|}
\hline Direct costs & Dynamic costs & Hidden costs \\
\hline $\begin{array}{l}\text { High transportation costs compared } \\
\text { with local sourcing } \\
\text { Quality problems } \\
\text { Longer lead time } \\
\text { Much higher transportation costs } \\
\text { Customs and duty costs } \\
\text { Transaction and insurance costs } \\
\text { Higher inventory costs because of the } \\
\text { long transportation time } \\
\text { Cost of quality control, investigation of } \\
\text { safety and environmental conformity } \\
\text { Extra cost to manage international } \\
\text { business, including extra cost of } \\
\text { bilingual professionals, agencies, } \\
\text { local personnel and travel }\end{array}$ & $\begin{array}{l}\text { Inventory destruction because of long transportation, } \\
\text { e.g., in case of quality problems } \\
\text { Increased transportation time and safety stock } \\
\text { because of demand volatility and variety } \\
\text { Much more investment in inventory because of long- } \\
\text { term transportation } \\
\text { High investment because of high quota restriction } \\
\text { High level of carbon emissions and environmental risk } \\
\text { Cost of lost sales and out-of-stock because of delayed } \\
\text { transportation } \\
\text { Cost of urgent and expedited shipments (e.g., air } \\
\text { freights) to provide continuous supply } \\
\text { Regular failure in transportation because of long } \\
\text { distances and poor infrastructure } \\
\text { Increased rules and regulations } \\
\text { Uncertainty because of supply failures and unsatisfied } \\
\text { consumer demand }\end{array}$ & $\begin{array}{l}\text { Increased wages in host country because of } \\
\text { rising living standards and market } \\
\text { competition } \\
\text { Communication problems because of lack of } \\
\text { personal discussion because of the distance } \\
\text { Lower responsiveness and lost or damaged } \\
\text { products } \\
\text { Loss of know-how } \\
\text { Fluctuation in interest rates } \\
\text { Cultural and time differences } \\
\text { Lack of corporate social responsibility } \\
\text { Political and economic instability and } \\
\text { possible terror attacks } \\
\text { Rise in transportation costs because of } \\
\text { higher oil price } \\
\text { Uncertainty over the long-term effect on } \\
\text { supply and demand } \\
\text { Lower profit because of hidden costs }\end{array}$ \\
\hline
\end{tabular}

Without considering and calculating the different dynamic, hidden and invisible costs of an offshore operation, organisations are unable to explore the true costs of the offshore operation. Calculating these costs also provides an appropriate analytical tool for comparison of the onshore and offshore costs of an operation. Hidden, dynamic, invisible and lifecycle costs are related to Total Cost of Ownership (TCO) calculation, which is discussed in the following theory section.

The literature and several cases around the world suggest that agility and responsiveness - the key factors in today's business - are rarely viable from a geographically far distance because these long distances create supply and production inefficiencies and increase logistical and inventory costs. A long-distance supply chain is unable to serve the main aspect of responsiveness - time. Responsive supply chains are generally applied by innovative product manufacturers; thus, the importance of proximity to the market for innovative product manufacturers is more crucial than for mass manufacturers.

\section{METHODOLOGY}

Previous studies on onshore manufacturing/local sourcing have adopted different approaches; however, they have commonly applied an interpretivism research strategy with a qualitative approach to investigate written data and their correlation with the emerged questions (Cagliano et al. 2012, Holweg et al. 2011, Ellram et al. 2013, Kazmer 2014). Supply chain management and operation research uses both qualitative and quantitative research methods; however, this study selected the qualitative method because this is the most suitable method to research areas in which the issues under study have a high degree of uncertainty, have not previously been studied, or have had only a few studies undertaken (Benbasat et al. 1987, Trauth 2001, Walsham 1995, Yin 2003). The secondary reason to select qualitative approach 
was the requirement of the alignment with situation and need for theory building. This research applied an exploratory, interpretive view of supply chain operations, with a single case study approach, alongside investigation of semistructured interviews which has been validated with survey study.

Creating the study foundation for knowledge and theory development, a structured literature review was utilised. To uncover relevant articles, papers from the last 15 years were reviewed. The journals were selected from high ranking, internationally recognized journals within the management, production, logistics and supply chain management area. For the purpose of finding the relevant papers, online database searches were conducted through each of the journals.

Offshore and onshore manufacturing were reviewed and compared and the following key terms were searched within journal databases: "international sourcing", "global sourcing" "local sourcing", "near sourcing", "low cost country sourcing", "offshore - onshore manufacturing", "offshore outsourcing". Furthermore, papers that contain "reshoring", "back-shoring", "moving back", "close-loop supply chain", "strategic cost management", "strategic flexibility". Because the terms "turbulent" or "volatile market environment" is always the starting point of the problem, papers were included if they contained any of the following concepts: "turbulent market environment", "volatile business environment". It is noticeable from the literature that "adaptability", "flexibility", "resilience" and "agility" are often used interchangeably. Thus, related papers were reviewed for the presence of flexible supply chain management, either in their abstract or in the body of the paper. As lean supply chain management was a focal point for several researchers and leaders in the last two decades, "lean management" and "lean supply chain" were the other key words also used.

Although a few articles were important to compare global and local sourcing, others were removed from the original list. Journal papers that produced a passing reference to, but did not examine the real target topics, were excluded from the investigation. According to Webster and Watson (2002), there are two other successful searching methods to find the right articles: examine backwards to uncover primary articles that this paper cites, or apply Web of Science and Google Scholar to uncover papers citing this article that may be relevant to the topic. This process resulted in several articles which were not included in any of the abovementioned high-ranking journals, but they discuss important and relevant issues within the onshore agile supply chain topic. However, while summarizing and structuring the literature may ensure the comprehensiveness of the coverage, it does not secure the integrity. Therefore, based on the relevance of the topic, several non-high-ranked articles were chosen in order to develop a deeper understanding of the concepts. Overall, seventy-seven papers were considered to be the foundation of the literature review.

\section{EMERGING THEORIES}

This paper presents a conceptual model of a viable onshore agile supply chain for frequent innovators in the manufacturing sector, for the purpose of achieving a conceptualised solution to assist in streamlining the supply chain. The process, outcome and research question of this study will be supported by the theoretical framework discussed below. By identifying gaps in the literature, this study has been able to develop a conceptual lens to detect issues of flexible supply chain solutions to be integrated into onshore manufacturing, before manufacturers decide whether to stay onshore or go offshore.

A brief review of the different theories in operation and supply chain management highlighted that three theories have been used more frequently than others, such as resource-based view (RBV) (Wernerfelt, 1984, Barney, 1991, Day, 1994, Chen et al. 2009, Bowersox et al. 2000). According to Chen et al. (2009 p.31), transaction cost analysis (TCA), (Cheon et al. 1995, Mcivor 2009, Tiwana \& Bush 2007, Williamson 1975), and Porter's five market forces (PFMF) (Porter 1998, Porter 2008, Young 2006). These three theories have been largely applied to studies reflecting the debate surrounding geographical distance in sourcing and production since the early 1980s, when RBV, TCA and PFMF were developed and used by several other researchers. However, for this research and for investigating the research question, in the process of reviewing the literature and considering other possible theories, two recent significant and relevant theories emerged. Both Dynamic Capabilities (DC) (Defee \& Fugate, 2010 Pettus et al. 2009, Zahra et al. 2006, Zollo \& Winter 2002) and Total Cost of Ownership analysis (TCO) (Degraeve et al. 2005, Degraeve \& Roodhooft 1999, Ellram 1995, Ellram \& Maltz 1995, Ellram and Siferd 1993, Garfamy 2006, Hartman et al. 2017, Moser 2011, Saccani et al. 2017, were identified in the area of turbulent and unstable business environments (Candace et al. 2011, Mohamud \& Sarpong 2016, Pezeshkan et al. 2015).

The RBV states that if the assets and resources of a firm are employed in distinctive ways, competitive advantage can be achieved (Wernerfelt 1984, Barney 1991, Day 1994, Chen et al. 2009). If at least a few of these resources are rare, valuable and difficult to replicate, competitive advantage can be achieved (Wernerfelt 1984, Barney 1991, Day 1994, Chen et al. 2009). RBV considers firms to have various different resources. This can only be the case however if it is assumed that the firm's environment is constant and relatively stable (D'aveni 1994). In a dynamic business environment, this will not hold true, because when companies experience rapidly changing environments, the advantage of a resource might soften or become less important over time, thus the assumptions of the RBV cannot be transferred to such markets (Teece 2007). According to this consideration, RBV is not the preferable theory for this research. TCA has the intention of minimising exchange costs in an organisation at the strategic level, both internally and externally (Tiwana \& Bush 2007). The fundamental elements producing transactional difficulties include environmental uncertainties, bounded rationality, opportunism and information impactedness (Cheon et al. 1995, Tiwana \& Bush 2007, Mcivor 2009). In general, when any of these elements rise, transaction costs increase. Furthermore, in the case of uncertainty and complexity in the business environment, transaction costs are higher.

As such, this theory was not suited to the current research because it did not provide full evaluation of a 
product that is sourced or produced offshore because of the several hidden, invisible and unpredicted costs involved. In the context of evaluating competitiveness, PFMF theory is another view of how organisations can be competitive by placing themselves in a strong position against competitors (Porter 1979, Porter 1998, Young 2006). These market forces reduce the potential profit in an industry. In defence against these forces, organisations should position themselves in an industry where the forces are at their weakest points or where the organisation is least vulnerable (Porter 1998). Overall, using Porter's theory, by reducing cost, differentiating a firm's product and placing the firm in the least vulnerable position regarding the five market forces, competitive advantage can be gained. PFMF does not addresses issues and solutions to achieving long-term competitive advantage in a volatile business environment (D'Aveni et al. 2010) and does not comment on the aspects of DC and TCO, thus it is not suited to the current research.

In contrast to the frequent application of RBV, TCA and PFMF in business research, DC and TCO have a stronger theoretical effect on business studies that focus on a volatile business environment (Candace et al. 2011, Mohamud and Sarpong 2016, Pezeshkan et al. 2015) where the research question is sensitive in terms of academic and businessrelated aspects. The conceptual framework of this study was built on the DC theory and TCO analysis. DC and TCO were purposefully selected to complement each other because, according several authors (Cox 1999, Mohamud \& Sarpong 2016; Pezeshkan et al. 2015), the complexity of today's supply chain system cannot be explained entirely with a single theory. In addition, combining these two theories can create a more complete understanding of the distant sourcing debate of innovative product manufacturers in an uncertain business environment. A single theory may have very limited analytical power; thus, combining these two theories can create a more complete understanding of the issues being explored - the distance sourcing debate of innovative product manufacturers in an uncertain business environment. The conceptual framework of this study was built on the DC theory and TCO analysis. The following sections explore these theories in more depth.

\subsection{Dynamic Capacity}

Teece et al. (1997 p. 516) defined DC as 'the firm's ability to integrate, build, and reconfigure internal and external competences to address rapidly changing environments. Dynamic capability is a well-known term among academics as it has been used by researchers since the middle of the twentieth century (Learned et al. 1969, Selznick 1957). In a time of turbulence, organisations should not create 'once-and-for-all' solutions and routines but should continually reconfigure and redesign the organisation's resources and capabilities. When the business environment is unpredictable or challenging, firms should revise their routines (March 1991). DC leads organisations to rethink their strategies about capabilities and resources (Zahra et al. 2006, Defee \& Fugate, 2010 Pettus et al. 2009). While functional capabilities are conceptualised as a firm's distinctive way of solving problems, DC refers to the ability to change 'the way the firm solves its problems' (Zahra et al. 2006 p. 920).
DC is not an 'ad hoc problem solving solution' or 'spontaneous fire-fighting activity'; rather, it represents a purposeful and identifiable process (Eisenhardt \& Martin 2000), a learnt and reliable pattern of common activities (Zollo \& Winter 2002) and a capability to achieve a purpose in an adequate and repetitive manner (Teece et al. 1997). The basic assumption of the DC framework is that core competencies should be used to modify short-term competitive positions that can be used to build longer-term competitive advantage. In other words, dynamic capability is the company's skill sets to integrate, build and reconfigure internal and external competences to react to the changing business environment. The combination of resources and capabilities represents the core capabilities of an organisation that allows it to outperform the competition (Teece et al. 1997). However, core capabilities can be insignificant or even dissuasive in the case of environmental changes, such as uncertainty in demand, exchange rate fluctuations and industry-based variations (Leonard-Barton 1992). Organisations in these conditions can create a trap for themselves if they do not react quickly to the required changes (Wang and Ahmed 2007, Teece et al. 1997). In these situations, DC is the primary organisational capability that can lead a firm to long-term success (Teece et al. 1997). The opposing option, such as global sourcing and offshore operations, does not appear to fit the DC theory (Parente et al. 2011) in a geographically distant situation, especially when supply chains involve operations in different continents. For example, when offshore manufacturers have to change a product, redesign a product, change a management strategy, develop innovation or sustain change, long term offshore operations can create difficulties for operations to react to the changing environment (Radjou 2000). Furthermore, capacity constraints and the inability to successfully respond to consumer requirements make global manufacturing inflexible (Cagliano et al. 2012, Holweg et al. 2011, Platt \& Song 2010, Stanczyk et al. 2017, Vos et al. 2016)

DC leads organisations to rethink their strategies about capabilities and resources (Zahra et al. 2006, Defee \& Fugate 2010, Pettus et al. 2009). Further research into the literature discovered topics on the deficiencies of DC theory. As Sirmon et al. (2010) explained, despite the popularity of DC in the recent literature on innovation research, several shortcomings still exist. For example, the relationship between DC and competitive advantage is inconsistent in several cases (Pezeshkan et al. 2015), as Pezeshkan and his colleagues argue that a competitive advantage cannot be sustainable in so-called 'hypercompetitive' environments. Hypercompetition represents a state of competition with rapidly escalating levels of competition and reduced periods of competitive advantage for firms (Fynes et al. 2007). D'Aveni and Ravenscraft (1994) also argued that firms that successfully transform multiple times may not necessarily be able to repeat this transformation in the future. Thus, after considering that DC might be unable to serve alone as the theoretical lens for this study, this study reviewed a broad range of theories in the operational, supply chain and innovation areas in order to supplement Dynamic Capabilities. The weaknesses of DC theory and the emerging topic about the sourcing debate raised the idea of implementing TCO into the theoretical framework, as discussed below. 


\subsection{Total Cost of Ownership Calculation}

Alongside the arrangement of resources and capabilities, organisations must also cautiously consider the real costs of offshore operations. For this reason, TCO was selected to complement DC. Traditionally, the actual prices of goods were the primary factor when selecting suppliers or deciding to implement offshore manufacturing (Degraeve \& Roodhoft 1999). However, firms have become more strategically aware of the importance and relevance of the indirect and hidden costs of international sourcing (Cousins \& Spekman 2003). As a result, decision makers have started to venture into examining the numerous indirect and lifecycle costs, besides the certain prices of goods and services from partners overseas. For this purpose, the TCO analysis has received extensive attention as a costmanagement tool and effective way to uncover the hidden, indirect costs inherent in offshore operations (Ellram 1993). To extend this view, Weber et al. (2010), Moser (2011) and Zachariassen and Arlbjorn (2011) stated that the TCO calculation is favoured to compare onshore and global operations and supply chains. An online TCO calculator, which was invented in the US by the Reshoring Initiative (Moser and Lang 2011) and supported by the US Government, for the purpose of examining the real cost of offshore manufacturing, highlights thirty-six different costs above Total Landed Cost that should be considered when planning to go offshore. This online calculator (http://reshorenow.org/tco-estimator/) raises the emerging question of whether manufacturers consider all 36 (or more) costs (hidden and unexpected) when planning to go offshore.

Manufacturers in general - and especially manufacturers with an innovative product - should carefully consider these factors before going offshore. Thus, applying TCO to purchasing, outsourcing or offshoring decisions can give organisations the potential to exploit TCO in a value analysis (Degraeve et al. 2005, Degraeve \& Roodhooft 1999, Ellram 1995, Ellram \& Maltz 1995, Ellram \& Siferd 1993, Garfamy 2006, Hartman et al. 2017, Moser 2011, Saccani et al. 2017, Weber et al. 2010, Zachariassen \& Arlbjorn, 2011).

In terms of TCO weaknesses, according to Hagman et al. (2016), TCO does not necessarily provide insight into the timing of the cost. Another disadvantage is that organisations only use TCO to minimise costs; however, they should consider how to maximise benefits - rather than choosing the cheapest solution, they should choose the application that provides the greatest benefit (NR, 2002). Furthermore, TCO is likely to reduce long-term costs; however, it also adds expense because of the need to gather more information, which increases workforce costs. Moreover, capturing the benefits of TCO analysis in a single year's budget can be difficult (FEC, 2006).

In consideration of the benefits, limitations and practical application of DC and TCO, this study applied both theories to investigate and answer the research question. In terms of the theoretical framework of this study, the above theories were applied to assess the appropriate combination of resources and capabilities, as well as to assess all the indirect, hidden, lifecycle and transaction costs of a product as part of the supply chain.

\section{THEORITICAL FRAMEWORK}

This paper focuses on frequent innovators (innovative manufacturers); hence, a question emerges regarding what framework can be applied for innovative manufacturers to achieve long-term competitive advantage in a volatile business environment. By utilising DC and TCO, a theoretical framework was developed incorporating all the relevant areas, such as the business environment, type of product, theories involved, type of managerial strategies, and geographical distance between manufacturing site and enduser and the potential to develop a more complete understanding of the research problem. Figure 1 demonstrates the theoretical framework that integrates both theories. The assumption of this study is that offshore operations may be a good decision to react to a changing environment; however, this decision may not be optimal in the long term. Managing a company remotely or managing a company in a different social and political environment can cause many unpredictable events (Markides \& Berg 1988, Stanczyk et al. 2017).

The theoretical framework presented in Figure 1 shows a different perspective of an operation. In terms of 'product type', this study focused on innovative product manufacturers. The 'environmental perspective' highlights that businesses currently operate in a volatile business environment. The 'theoretical perspective', includes the two selected theories of DC (which suggests that companies should frequently integrate, build and reconfigure internal and external competences to promptly react to the changing environment) and TCO (which proposes that organisations should wisely calculate all the indirect, hidden, lifecycle and transaction costs of a product when considering moving production offshore). The third important aspect of the theoretical framework is the 'operational perspective', which recommends applying an agile supply chain, strategic flexibility and a high level of responsiveness for manufacturers with innovative products. The fourth important perspective is the 'geographical perspective', which recommends proximity to the market to enable reactions to customer requirements and the changing business environment. The opposing option of offshore manufacturing does not appear to fit the DC theory (Parente et al. 2011) in a geographically and culturally distant situation, especially when supply chains involve operations in different continents. 


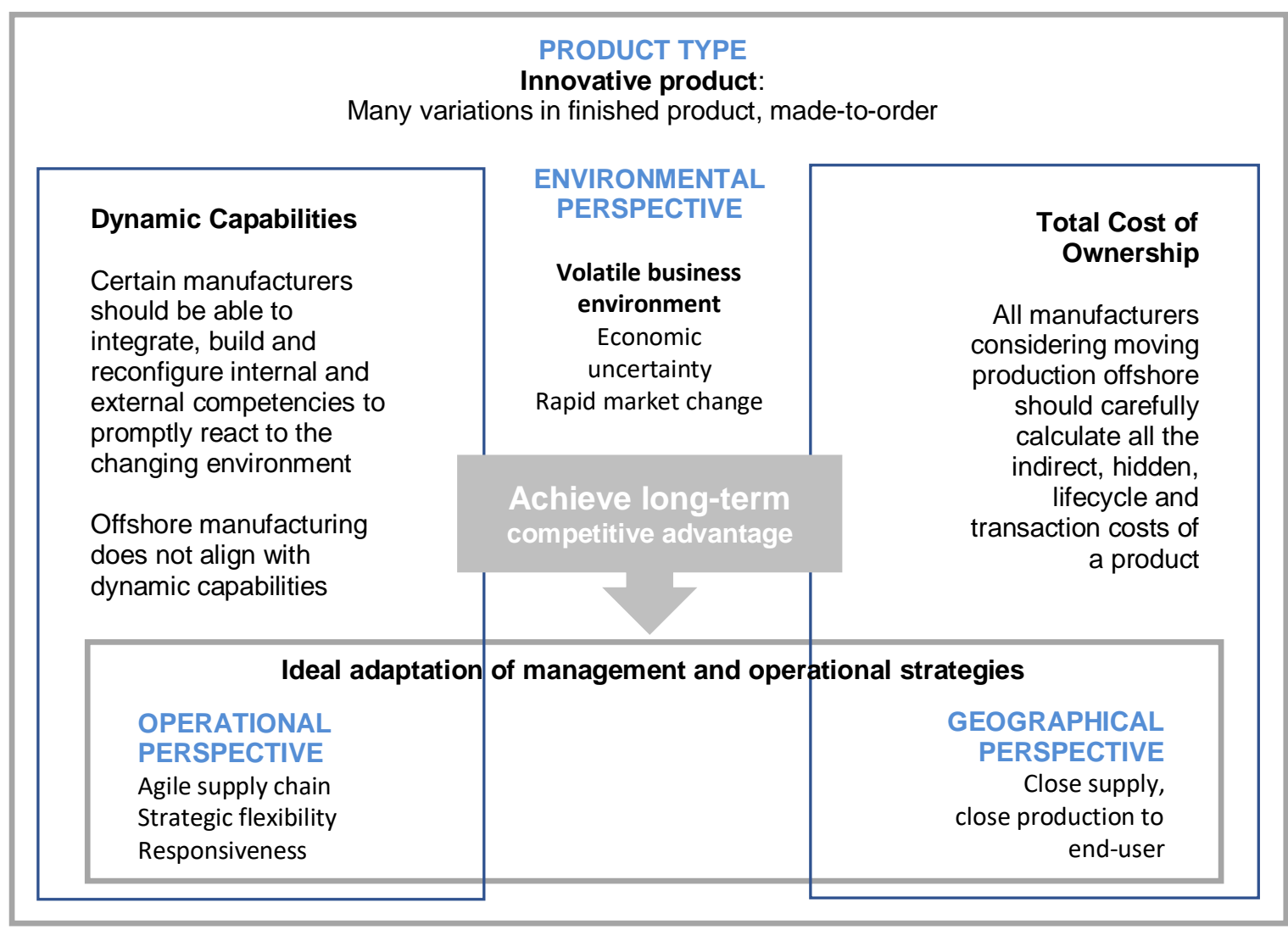

Figure 1 Theoretical Framework

Removing one theory from the theoretical framework would reduce the strength of the true evaluation of the phenomenon. For instance, a manufacturer may have already examined and implemented different operational, production and supply chain activities, yet those strategic movements have not truly assisted the company to gain competitive advantage. This company is considering moving offshore and calculated only the visible cost of the overseas operation. Without a comprehensive TCO calculation, this company would decide to move overseas and may regret this decision later, due to the lack of consideration given to hidden, unexpected, and transactional costs. Furthermore, if a manufacturer investigates all the accurate future costs of an offshore or global operation, yet does not implement any strategic changes, they may think that overseas production will be beneficial. Thus, both strategic actions of DC and the TCO calculation should be considered when manufacturing enterprises encounter difficulties. For the first time, this research has combined DC and TCO calculation in a theoretical framework and suggested applications for practitioners.

The research propositions developed below connect to the theoretical framework above. In the specific case of the manufacturing sector, with the assumption that manufacturers have to conform to the recent volatile environment and market demand, local sourcing and onshore manufacturing can be the most effective possibility to produce innovative product and serve customer demand efficiently. Managing a company remotely or managing a company in a different social and political environment can cause many unpredictable events. However, gaining competitive advantage in a turbulent market environment means strategic flexibility is required.
Proposition 1: There is a positive relationship between increased environmental turbulence and the likelihood that firms will become aware of the need for flexibility, i.e. they must repeatedly reconfigure resources and capabilities in order to remain competitive.

In the last ten years, global economic uncertainty and volatility has weakened the benefits of global sourcing as greater risks appear. Butner (2010 pg 24) stated that "as compliance mandates, suppliers, and information flows multiply, supply chains are becoming more complex, costly, and vulnerable". International sourcing and offshore manufacturing can result in bigger investments due to long transportation and it can create several hidden costs, not to mention the difficulties of managing outsourced manufacturing remotely. According to Christopher et al. (Christopher \& Holweg 2011) organizations that have a flexible supply chain, including a local-sourcing strategy combined with lean and agile principles in their operations, are able to respond more quickly to the ever-fluctuating customer demand and increasingly turbulent market compared to firms who utilize global sourcing.

Proposition 2: The more rapidly market and competitive conditions change, the more likely it is that a firm will rely on local sourcing and onshore manufacturing, i.e. the closer the production is to the marketplace, the quicker end-user response can be achieved

When competitive advantage comes from speed and a track record of reliability, offshore manufacturing often is not the right strategy. According to Stanczyk et al. (2017) 
these days, speed has become a competitive weapon and it can create a trap if a supply chain becomes complex, robust and slow.

Proposition 3: Onshore manufacturing and local sourcing is positively related to successfully serving a flexible supply chain.

Recently, global economic uncertainty and volatility has weakened the benefits of global sourcing as greater risks appear (Butner, 2010). Furthermore, associated with distance, supply chains are becoming more complex, costly, and vulnerable (Picker 2016, Jia et al. 2017). Although product prices are much lower in Asian countries, supply chain complexity, difficulties of supply and logistics, volatility in the business environment and several other aspects lower the benefit of international sourcing (Butner, 2010). International sourcing and offshore manufacturing can result in bigger investments due to long transportation, and it can create several hidden costs, as Table 1 describes, not to mention the difficulties of managing outsourced manufacturing remotely. Moreover, global sourcing has an intention to increase complexity, which works against agility. Even if high level agility has been implemented in the supply chain, flexibility is impossible due to a complex global sourcing strategy.

Proposition 4: The greater the reliability on global sourcing, the greater the chance of losing agility and flexibility.

In recent supply chain trends, markets are increasingly interconnected, outsourcing, or offshoring, are becoming more common, and companies are concentrating mostly on their core competencies (Liu et al., 2010). Nevertheless, emerging risk can impact the benefit of global businesses, weaken companies' reputation and weaken competitiveness (Liu et al. 2010, Vos et al. 2016). As reported by Christopher et al (2011), poor synchronization in the supply chain is frequently caused by outsourcing and offshoring decisions. Furthermore, product complexity (variance on components, suppliers, manufacturers, transportation paths), communication failures, misunderstanding product requirements, and misleading the brand's strategy seem to be the key risk of global sourcing (Christopher et al. 2011). As Christopher at al. (2011) also states, global sourcing makes supply chains longer and more disintegrated, thus causing firms greater risk and cost. Uncertainty and complexity increase external vulnerability. Logistically difficult geographic regions and the number of regions covered by the supply chain increase uncertainty and supply chain exposure (Prater et al., 2001, Aitken \& Bozarth 2016). Each political area or border that a supply chain must cross can pose problems.

Proposition 5: There is a positive relationship between supply base complexity and supply risk that the focal company assumes when working with its offshore outsourcing supply base.

Supply chain partners must possess a culture of viewing the supply chain as a whole and of recognizing the need for cooperative efforts (Defee and Fugate 2010). Sophisticated organizational and strategic routines are the foundation of dynamic capabilities (Turner et al. 2018, Zollo \& Winter, 2002), which assist to rearrange and refresh resources of the supply chain to make viable and economically value-creating strategies (Asmussen 2018, Pettus et al. 2009). Thus, these capabilities are the elementary drivers of the configuration of other resources to provide new possibilities of growth (Henderson and Cockburn 1994). As partners in the supply chain increase their competence to share and combine resources and knowledge innovatively, advantageous capabilities may result. The collaboration of an effective supply chain can assist in creating new cross-organizational capabilities that makes supply chains more competitive and less vulnerable to competitors that less effectively actualize innovative capabilities (Mentzer 2004).

Proposition 6: The greater the dynamic capability of a supply chain, the greater it can utilize strategic flexibility, and the more effectively it can engage in resources configuration.

Dynamic capabilities result from complicated organizational and strategic routines (Haris et al 2018, Zollo \& Winter 2002) through which managers reconfigure and renew a firm's resource base to generate economically valuecreating strategies (Araceli et al. 2018, Foss 1996, Pettus et al. 2007, Pisano 1994). Thus, these capabilities are the fundamental drivers of the creation, evolution and recombination of other resources to provide new sources of growth (Henderson 1994, Henderson and Chen et al. 2019, Yander \& Kogut 1995). As supply chain members improve their ability to share and combine resources and knowledge in novel ways, new and innovative capabilities may result. The synergies produced by supply chain partners coevolving to create new firm-specific and crossorganizational capabilities makes the supply chain more competitive and less susceptible to rival supply chains that are not as proficient in continuously creating innovative capabilities (Brewer \& Speh 2000, Mentzer 2004, MoraMonge et al. 2019).

Proposition 7: Extending dynamic capabilities across multiple organizations in a supply chain leads to a positive relationship to successfully add value and gain competitive advantage

Combining agile supply chain management with the recognition of TCO and increased customer demand for shorter supply chains and faster responses will help organizations gain competitive advantage (Moser 2011, Visani et al. 2016, Bitencourt et al. 2019). The greater the reliability on flexible supply chain management, the greater the possibility that after the TCO calculation, organizations may decide on onshore manufacturing for the purpose of achieving competitive advantage

\section{DISCUSSION}

In this paper, Dynamic Capabilities and the Total Cost of Ownership theories have been combined in order to supplement each other. For the first time, the combination of 
DC and TCO theories have been used as a lens to examine the onshore/offshore debate. A search of the academic literature discussing the combining of Dynamic Capabilities and the Total Cost of Ownership in the context of this study has not been conducted and the power of these theories assists in explaining the phenomenon of this study. The theoretical framework also showed that the specific choice of the combined theories can help organisations maximise the desirable characteristics of their operational outcome. In this study, the theoretical framework applied two theories that supplemented each other: DC and TCO. To investigate the viability of the competitive advantage of a company in a rapidly changing business environment or when a manufacturer is struggling with uncertainty in customer demand and considering moving production offshore to save costs, this study suggested incorporating two investigations utilising the two proposed theories of DC and TCO. Firstly, manufacturers should examine their main operation and management strategy and their resources and capabilities and make prompt changes to meet customer and stakeholder requirements. If necessary, manufacturers should change production strategy, such as implementing well-known successful operations or production activities - not only through the core company, but also throughout the whole supply chain. Alternatively, the manufacturer could implement different changes, such as changing marketplace or product type. Secondly, companies should consider all the invisible and hidden costs of offshore operations by considering all elements of the online TCO calculator to be able to investigate all the unexpected future costs and undesirable events associated with overseas production.

In recent supply chain trends, markets are increasingly interconnected, outsourcing or offshoring are more common, and companies are concentrating on their main competencies (Liu et al. 2010). Expanded supply chains could provide companies with operational effectiveness, which can lead those organisations to achieve high market performance and competitiveness. Nevertheless, emerging risk can reduce the benefits of global businesses, weaken a company's reputation and damage competitiveness (Liu et al. 2010). There are many possible ways for organisations to gain competitiveness; however, in a turbulent market environment, strategic flexibility is required. The direction of a firm's expansion may be unclear; thus, firms need to implement agility in terms of renewing existing resources, changing their resource position and refreshing their capabilities to be able to adapt to changing customer demand (Smith \& Grimm 1987). Strategic flexibility requires organisational routines to reconfigure a firm's resources to respond to specific environmental changes (Zollo \& Winter 2002). By maximising the productivity of a certain set of new resources, firms will learn and gain achievement from the contribution of new resources. Meanwhile, the TCO calculation will assist organisations to evaluate the real cost of offshore operations.

Having the theoretical framework built up from the literature, the literature also supports the above approaches to reacting to uncertainties, long lead times and large inventories. As the theoretical framework suggests, business environment uncertainties can be managed with the implementation of DC, which involves reassessing resources and capabilities frequently, and changing business, market or operational strategies if, and when, necessary. Thus, this theoretical framework can be applied to assist manufacturers to resolve situations that affect their operations. Manufacturers with innovative products operate more efficiently closer to the market, because an effective and responsive operation is only viable within a close distance. Hence the proposed theoretical framework is essential for manufacturers with innovative products but can be applicable to any production related company.

As a reflection on the extant literature this paper explores how agility can add value to onshore operations and local supply chains among innovative product manufacturers to potentially gain competitive advantage. During the last five years, with volatility in the business environment increasing significantly (Candace et al. 2011, Christopher et al. 2011), the concepts of local sourcing strategies and onshore manufacturing has been one of the components of flexible supply chains for Australian manufacturers with innovative products (Fantazy et al. 2012, Georgiadis et al. 2011). These concepts provide quick customer response and increase final value by modifying the production process for the purpose of gaining competitive advantage (Abdulla 2009, Butner 2010, Christopher \& Holweg 2011, Mentzer 2004). While offshoring is a good strategy for lowering costs and prices for the end customer, there are inefficiencies caused by the shift away from local sourcing, such as less flexibility and slower response to changing customer demands. A recent trend in Europe and the US is to remove outsourcing and return to local sourcing (Ashby 2016, Wiesmann et al. 2017, Moradlou et al. 2017)

Environmental uncertainties, volatile economic situations around the world, a fast-moving business environment and customer demand creates the need for quick response to end-users, which requires local, agile supply chain_solutions (Christopher \& Holweg 2011). To achieve a competitive priority, manufacturers may need to reconsider their operations, and manufacture or source their products closer to the end-user. There are a growing number of examples (Chaudhry \& Hodge 2012, Cooper et al., 1997, Georgiadis et al., 2011; Lau and Lee 2000; Sharma 2010; Stavrulaki \& Davis 2010) of individual businesses no longer operating separately, but as a supply chain. For this reason, this study examined this phenomenon as an overall supply chain-related problem, rather than as a single business issue. The last column of Table 2 . provides details about the extended work of this study.

\section{CONCLUSION}

Reviewing numerous studies related to global sourcing, nearshoring, reshoring, and back-shoring activities, as well as 'best-practice' on these topics, provided the possible knowledge gap that was identified. Table 2. illustrates the details of the identified knowledge gap. 
Table 2 Contributions of this study

\begin{tabular}{|c|c|c|c|}
\hline Author/Title & Title & Findings & Extended work based on Gyarmathy (2018) \\
\hline $\begin{array}{l}\text { Christopher, } \\
\text { Holweg, } 2011\end{array}$ & $\begin{array}{l}\text { Supply Chain 2.0: } \\
\text { managing supply } \\
\text { chains in the era of } \\
\text { turbulence }\end{array}$ & $\begin{array}{l}\text { Organisations used to aim for efficiency through } \\
\text { "optimized" supply chains, but now it is important to } \\
\text { build supply chains that are adaptable to turbulence. } \\
\text { 'Low-cost country advantage' generally outweighs the } \\
\text { transportation cost in global supply chains no longer } \\
\text { holds. }\end{array}$ & $\begin{array}{l}\text { As a response to volatile business } \\
\text { environment, agility and responsive supply } \\
\text { chain closer to end-user should be considered } \\
\text { in several cases. }\end{array}$ \\
\hline $\begin{array}{l}\text { Ritter and } \\
\text { Sternfels, 2004 }\end{array}$ & $\begin{array}{l}\text { When offshore } \\
\text { manufacturing } \\
\text { doesn't make sense }\end{array}$ & $\begin{array}{l}\text { Too many organizations overestimate the savings to be } \\
\text { had from going abroad and fail to recognize the } \\
\text { problems, such as dealing with inventory, } \\
\text { obsolescence, and currency exchange rates. }\end{array}$ & \multirow{3}{*}{$\begin{array}{l}\text { Offshoring often isn't the right strategy for } \\
\text { companies whose competitive advantage } \\
\text { comes from speed and a track record of } \\
\text { reliability. Onshore or nearshore operation with } \\
\text { proximate supply chain solution in several } \\
\text { instances has more benefit. }\end{array}$} \\
\hline Pagani, 2004 & $\begin{array}{l}\text { Manufacturing execs } \\
\text { should focus on } \\
\text { becoming lean before } \\
\text { going offshore }\end{array}$ & $\begin{array}{l}\text { Recently, there is a trend towards offshore production } \\
\text { and sourcing may be reversing. Quite a number of } \\
\text { manufacturers have realized that off-shoring may not } \\
\text { be as advantageous as previously thought. This is } \\
\text { probably because they did not consider factors other } \\
\text { than monetary costs. }\end{array}$ & \\
\hline Williams, 2009 & $\begin{array}{l}\text { International } \\
\text { sourcing: Offshore or } \\
\text { Near-shore? }\end{array}$ & $\begin{array}{l}\text { Three/quarters of major US companies currently } \\
\text { sourcing internationally have made changes or are } \\
\text { planning to make changes to alter operations and } \\
\text { supply chains to source closer to the end-user. } \\
\text { Advantages are shorter, more reliable delivery time, } \\
\text { lower shipping cost, to get relief from cost of late } \\
\text { deliveries, as well as warranty and safety costs. }\end{array}$ & \\
\hline $\begin{array}{l}\text { Holweg, } \\
\text { Reichhart, Hong, } \\
2011\end{array}$ & $\begin{array}{l}\text { On risk and cost in } \\
\text { global sourcing }\end{array}$ & $\begin{array}{l}\text { Many global sourcing ventures do yield less than } \\
\text { expected benefit - or are in fact not economically viable } \\
\text { - due to unexpected hidden and dynamic costs. As the } \\
\text { demand uncertainty is often driven by product variety, } \\
\text { high-variant products tend to be less suitable for global } \\
\text { sourcing. }\end{array}$ & $\begin{array}{l}\text { Manufacturing executives should think of } \\
\text { becoming lean, agile of leagile before leaping } \\
\text { offshore }\end{array}$ \\
\hline Picker, 2016 & $\begin{array}{l}\text { Manufacturing in } \\
\text { America: The Real } \\
\text { Benefits and the } \\
\text { Drawbacks } \\
\text { Reshoring }\end{array}$ & $\begin{array}{l}\text { If the US offshores most of its plants to Asia, there will } \\
\text { be no viable supply chains remaining in the US, and } \\
\text { nothing can done if Asian suppliers decide to raise } \\
\text { prices }\end{array}$ & $\begin{array}{l}\text { Although locally manufactured goods cost } \\
\text { slightly more than imports, they are closer to } \\
\text { home, require shorter transportation, are higher } \\
\text { quality and arrive on time. }\end{array}$ \\
\hline Vos et al., 2016 & $\begin{array}{l}\text { Does global sourcing } \\
\text { pay-off? A } \\
\text { competitive dynamics } \\
\text { perspective }\end{array}$ & $\begin{array}{l}\text { Product complexity; variance in components, suppliers, } \\
\text { manufacturers and transportation paths; } \\
\text { communication failures; misunderstanding of product } \\
\text { requirements and misleading the brand's strategy are } \\
\text { the key risks of global sourcing }\end{array}$ & $\begin{array}{l}\text { Poor synchronisation in the supply chain is } \\
\text { frequently caused by outsourcing and } \\
\text { offshoring decisions. }\end{array}$ \\
\hline $\begin{array}{l}\text { Aitken and } \\
\text { Bozarth, } 2016\end{array}$ & $\begin{array}{l}\text { To eliminate or } \\
\text { absorb supply chain } \\
\text { complexity: a } \\
\text { conceptual model and } \\
\text { case study }\end{array}$ & $\begin{array}{l}\text { Even if high-level agility has been implemented in the } \\
\text { supply chain, flexibility is impossible because of the } \\
\text { complex global sourcing strategy }\end{array}$ & $\begin{array}{l}\text { Global sourcing increases complexity, which } \\
\text { works against agility. }\end{array}$ \\
\hline $\begin{array}{l}\text { The Australia } \\
\text { Institute, } 2016\end{array}$ & $\begin{array}{l}\text { Manufacturing (still) } \\
\text { matters }\end{array}$ & $\begin{array}{l}\text { Australia should keep and sustain its manufacturing } \\
\text { sector, and referred to statistical evidence to confirm } \\
\text { that, when countries properly orient their economic, } \\
\text { trade and technology policies, even high-wage } \\
\text { countries can maintain the economic output of their } \\
\text { manufacturing sectors at a high level }\end{array}$ & $\begin{array}{l}\text { Incorrect assumption which indicates that the } \\
\text { manufacturing operation of remote and small } \\
\text { domestic countries such as Australia would be } \\
\text { unfeasible, because several other remote and } \\
\text { small economies around the world have } \\
\text { outperformed Australia in manufacturing } \\
\text { activity. }\end{array}$ \\
\hline $\begin{array}{l}\text { Eltawy and } \\
\text { Gallear, } 2017\end{array}$ & $\begin{array}{l}\text { Leanness and agility: } \\
\text { a comparative } \\
\text { theoretical view }\end{array}$ & $\begin{array}{l}\text { The combination of lean and agile models maintains a } \\
\text { new way of thinking in the context of supply chain } \\
\text { management. A flexible and quick response to market } \\
\text { demands in conjunction with a lean paradigm are } \\
\text { mutually opposing principles }\end{array}$ & $\begin{array}{l}\text { If lean and agile approaches are operated } \\
\text { wisely with a decoupling point, organisations } \\
\text { can achieve competitive advantage in their } \\
\text { proximate business environment. }\end{array}$ \\
\hline Kara et al., 2014 & $\begin{array}{l}\text { Sustainable product } \\
\text { development } \quad \text { in } \\
\text { practice: an } \\
\text { international survey }\end{array}$ & $\begin{array}{l}\text { The predictable demand of functional products means } \\
\text { that market mediation operates smoothly because } \\
\text { demand and supply are almost equal. In that instance, } \\
\text { the supply chain focuses only on minimising physical } \\
\text { cost as the essential goal of a cost-sensitive functional } \\
\text { product }\end{array}$ & $\begin{array}{l}\text { High variant, innovative products tend to be } \\
\text { less suitable for global sourcing. Location factor } \\
\text { in terms of supply chain management in this } \\
\text { instance is highly relevant }\end{array}$ \\
\hline
\end{tabular}


Table 9 Contributions of this study (cont')

\begin{tabular}{|c|c|c|c|}
\hline Author/Title & Title & Findings & Extended work based on Gyarmathy (2018) \\
\hline $\begin{array}{l}\text { Hartman et al., } \\
2017\end{array}$ & $\begin{array}{l}\text { Nearshoring, } \\
\text { reshoring, and } \\
\text { insourcing: moving } \\
\text { beyond the total cost } \\
\text { of ownership } \\
\text { conversation. }\end{array}$ & $\begin{array}{l}\text { The findings from this case study suggest that the } \\
\text { current manufacturing relocation shift is not perceived } \\
\text { by manufacturers as a long-term business strategy (as } \\
\text { outsourcing has been). As such, the results suggest } \\
\text { that manufacturing relocation decisions based } \\
\text { exclusively on models such as total cost of ownership } \\
\text { (TCO) will not deliver anticipated near-term costs } \\
\text { savings. }\end{array}$ & $\begin{array}{l}\text { The most important reasons for reshoring and } \\
\text { apply agile supply chain are based on wage } \\
\text { and currency exchanges, quality and warranty } \\
\text { problems, increased freight costs, unreliable } \\
\text { deliveries, increased inventory, intellectual } \\
\text { property loss or risk, misleading total cost } \\
\text { calculations and difficult communications }\end{array}$ \\
\hline $\begin{array}{l}\text { Singh et al., } \\
2017\end{array}$ & $\begin{array}{l}\text { Analysing the } \\
\text { interaction of factors } \\
\text { for flexibility in supply } \\
\text { chains }\end{array}$ & $\begin{array}{l}\text { Innovative products-with their unpredictable demand } \\
\text { and short lifecycle-increase the risk of shortage of } \\
\text { supply; hence, the predominant cost of innovative } \\
\text { products is always the market mediation cost }\end{array}$ & $\begin{array}{l}\text { The most important issue in supply chains } \\
\text { dealing with innovative products is to realise } \\
\text { early sales numbers and different market } \\
\text { signals, and to react quickly due to the short } \\
\text { lifecycle of the product Apply onshore or } \\
\text { nearshore operation and supply chain in those } \\
\text { instances would be more beneficial. }\end{array}$ \\
\hline $\begin{array}{l}\text { Fel \& Griette. } \\
2017\end{array}$ & $\begin{array}{l}\text { Near-reshoring your } \\
\text { supplies from China: } \\
\text { a good deal for } \\
\text { financial motives too }\end{array}$ & $\begin{array}{l}10 \text { per cent of companies in Europe plan to near- } \\
\text { reshoring soon. The authors determine main motives } \\
\text { for near-reshoring and show that companies having } \\
\text { reshored are very satisfied in terms of product quality, } \\
\text { responsiveness between order and delivery. }\end{array}$ & $\begin{array}{l}\text { Trends within European manufacturers towards } \\
\text { nearshoring and proximate supply chain } \\
\text { solutions with new manufacturing models to } \\
\text { successfully compete in high-labour-rate } \\
\text { markets are arise. }\end{array}$ \\
\hline
\end{tabular}

The conclusion of the table is that for some companies, the best way to streamline the supply chain will be to bring manufacturing and sourcing closer to home (Kara et al 2014, Fel and Griette, 2017). For others this may not be the best solution (Jia et al. 2017, Platt \& Song 2010). A broad range of factors related to each company's specific situation will dictate those needs (Aitken \& Bozarth 2016, Christopher \& Holweg 2011). This study determines whether there is any particular type of manufacturer that can stay local and whether agile operations add value to those manufacturers that decide to stay onshore and apply proximate supply chain solutions.

This study focuses on frequent innovators; thus, a question emerges regarding what the optimal solution for innovative manufacturers is to achieve long-term competitive advantage in a volatile business environment. The above theoretical framework summarises all the related areas examined in this study, such as business environment, type of product, theories involved, type of managerial strategies, and geographical distance between manufacturing site and end-user. According to the theoretical framework, these factors together determine sustainable competitive advantage in a successful supply chain.

The theoretical contribution of combining these two theories is that companies should not only assess visible costs, but also implement strategic changes and consider invisible and hidden costs when examining the viability of local production. This study developed a theoretical framework that investigated how companies can manipulate their sources and capabilities (Dynamic Capabilities, DC) in a rapidly changing environment, the relevant antecedents and outcomes, and how to apply the Total Cost of Ownership (TCO) calculation, before proposing to move offshore.

As a reflection of the research question, a firm's application of strategic agility into their process to adapt to increased environmental turbulence can be achieved most ideally in the same business environment where the demand occurs (Aitken \& Bozarth 2016, Eltawy \& Gallear 2017). By building strategic agility and applying near term supply chain, efficient and responsive production can be achieved, which helps firms react promptly and successfully to volatile market demand, as well as overcome fluctuations and uncertainty in customer demand (Singh et al. 2017, Vos et al. 2016). The structure of this study research accommodated the emerging question of the onshore-offshore debate in a changing business environment.

Three primary practical contributions emerged from this study. Firstly, this paper addresses the issue of the possible limits of the offshore environment to operating efficiently and meeting customer demand without constraints. The literature indicates that firms seeking to optimise their opportunities through global sourcing may not always be viable. Local sourcing and onshore manufacturing are essential when a supply chain strategy focuses on core competencies and on achieving improvements in profitability, efficiency and flexibility. Furthermore, manufacturers should increase their local supply chain strategy, considering that numerous global sourcing ventures among frequent innovators are not economically viable because of its robust and inflexible supply chain as well as the numerous unexpected, hidden and dynamic costs

The present analysis has certain limitations, with further review recommended to determine the viability of this theoretical framework for different cultural and geographical distances. This research mainly addresses the issue of avoiding offshore manufacturing between continents, whereas sourcing within the same continent could be feasible. Hence, further research could consider the link between cultural and geographical distance regarding operational and managerial strategies. Other criteria may need to be applied to firms that mostly source simple semifinished or finished commodities from overseas, or mass manufacturers that decide to implement offshore operations. Overall, by measuring the advantages and disadvantages associated with geographical and cultural distances, decisions cannot yet be investigated satisfactorily, and require further attention.

From an academic standpoint, this research represents one of the initial exploratory studies to focus on agile supply chain management along with onshore manufacturing. 
Specifically, this research: 1). developed and tested a theoretical framework that investigated how companies can manipulate their sources and capabilities in a rapidly changing environment, the relevant antecedents and outcomes, and how to apply TCO calculations (including hidden, invisible and lifecycle costs) before proposing to move offshore; 2). provided a valid and reliable understanding of the advantages of local supply chain, and business contextual dynamism for consumer requirements; and 3). contributed to the literature by applying this conceptual model to the manufacturing industry worldwide. In conclusion, this paper has not only provided an exploratory foundation for future research on the subject of agile, local supply chains, but has also developed a theoretical framework to aid in reacting to a volatile supply chain and market environment.

\section{REFERENCES}

Abdulla, S.A.A., (2009), Strategies for competitive advantage and supply chain management: synergy opportunities, $\mathrm{PhD}$ thesis, A\&M University, Texas.

Aitken, J. and Bozarth, C. (2016), To eliminate or absorb supply chain complexity: a conceptual model and case study, Supply Chain Management: An International Journal, 21(6), pp. 759-774.

Arika, A. (2013), Framing the offshoring and re-shoring debate: a conceptual framework, The Journal of Global Business Management, 9, 73-83.

Ashby, A. (2016), From global to local: reshoring for sustainability, Operations Management Research, 9 (3-4), pp. 75-88

Asmussen J.N., Kristensen, J., Wæhrens and Brian V. (2018), Cost estimation accuracy in supply chain design, International Journal of Physical Distribution \& Logistics Management, 48 (10), pp. 995-1019.

Aslam H., Blome C., Roscoe, S. and Azhar, T., (2018) Dynamic supply chain capabilities, International Journal of Operations \& Production Management, 38 (12), pp. 2266-2285.

Barney, J. B. (1991), Firms resources and sustained competitive advantage, Journal of Management 17 (1), pp. 99-120.

Bitencourt, C.C.deO.S., Fernando, Wagner J., Santos A.C. Teixeira, E.K., (2019) The extended dynamic capabilities model: A meta-analysis, European Management Journal, 38 (1), pp. $108-120$.

Benbasat, I., Goldstein, D. and Mead, M. (1987). The Case Research Strategy in Studies of Information Systems. MIS Quarterly, 11(3), pp. 369 - 386.

Bowersox, D.J., Closs, D.J. and Stank, T.P. (2000), Ten mega trends that will revolutionalize supply chain and logistics, Journal of Business Logistics, 21(2), pp. 1-15.

Butner, K. (2010), The smarter supply chain of the future, Strategy \& Leadership, 38(1), pp. 22-31.

Cagliano, A. C., De Marco, A., Rafele, C. and Arese, M. (2012), A decision-making approach for investigating the potential effects of near sourcing on supply chain, Strategic Outsourcing: An International Journal, 5(2), pp. 100-120.

Candace, Y. Y., Ngai, E. W. T. and Moon, K. L. (2011), Supply chain flexibility in an uncertain environment: exploratory findings from five case studies, Supply Chain Management: An International Journal, 16(4), pp. 271-283.

Chaudhry, H. and Hodge, G. (2012), Postponement and supply chain structure: cases from the textile and apparel industry, Journal of Fashion Marketing and Management, 16(1), pp. 64-80.

Chen, C. (2019), Developing a model for supply chain agility and innovativeness to enhance firms' competitive advantage, Management Decision, 57(7), pp. 1511-1534.
Chen, H., Daugherty, P. J. and Landry, T. D. (2009), Supply Chain Process Integration: A Theoretical Framework, Journal of Business Logistics, 30(2), pp. 27-46.

Cheon, M. J., Grover, V. and Teng, J. T. C. (1995), Theoretical perspectives on the outsourcing of information system, Journal of Information Technology, 10(4), pp. 209-219.

Chopra, S and Meindl, P (2007), Supply Chain Management, Strategy, Pearson Education Textbook, Kellog Business College, US

Christopher, M and Holweg, M 2011, Supply Chain 2.0": managing supply chains in the era of turbulence, International Journal of Physical Distribution \& Logistics Management, 41(1), pp. 63-82.

Christophe, M., Mena, C., Khan, O. and Yurt, O. (2011), Approaches to managing global sourcing risk, Supply Chain Management: An International Journal, 16(2), pp. 67-81.

Cooper, M.C., Lambert, D.M. and Pagh, J.D. (1997), Supply chain management: more than a new name for logistics, International Journal of Logistics Management, 8 (1), pp. 114.

Cousin, P. D. and Spekman, R. 2003. Strategic supply and the management of inter-and intra organisational relationships, Journal of Purchasing \& Supply Management, 9 (1), pp. 1929.

Cox, A. (1999), Power, value and supply chain management, Supply Chain Management: An International Journal, 4(4), pp.167-175.

D'Aveni, RA, Dagnino, G.B, and Smith KG 2010, The age of temporary advantage, Strategic Management Journal, 31 (13), pp. 1371-1385

D'aveni, R. A. and Ravenscraft, D. J. (1994), Economies of Integration Versus Bureaucracy Costs: Does Vertical Integration Improve Performance?, Academy of Management Journal, 60(5)

Day, G. (1994), The Capabilities of Market-Driven Organizations, Journal of Marketing, 58(4), pp. 37-52.

Defee, C. C. and Fugate, B. S. (2010), Changing perspective of capabilities in the dynamic supply chain era, International Journal of Logistics Management, The, 21(2), pp. 180-206.

Degraeve, Z., Roodhoft, F. and Van Doeren, B. (2005), The use of total cost of ownership for strategic procurement: a companywide management information system, Journal of the Operational Research society, 56(1), pp. 51-59.

Degraeve, Z. and Roodhooft, F. (1999), Improving the efficiency of the purchasing process using total cost of ownership information: The case of heating electrodes at Cockerill Sambre S.A., European Journal of Operational Research,112(1), pp. 42-53.

Eisenhardt, K and Martin, J (2000), Dynamic capabilities: what are they?, Strategic Management Journal, 21(10-11), pp. 11051121.

Ellram, L. M. (1995), Total cost of ownership: an analysis approach for purchasing, International Journal of Physical Distribution \& Logistics Management, 25(8), pp. 4-23.

Ellram, L. M. and Maltz, A. (1995), Use of the Total cost of Ownership Concepts to Model the Outsourcing Decision, International Journal of Logistics Management, 6(2), pp. 5566.

Ellram, L. M. and Siferd, S. P. (1993), Purchasing: The cornerstone of the Total Cost of Ownership concept, Journal of Business Logistics, 14(1), pp.163-185.

Eltawy, N. and Gallear, D. (2017), Leanness and agility: a comparative theoretical view, Industrial Management \& Data Systems, 117(1), pp. 149-165.

Fantazy, K.A., Mukerji, B. and Kumar, R. (2012), Relationship between supply chain strategies, logistics flexibility and supply chain performance: evidence from Canadian manufacturing industry, International Journal of Logistics Systems and Management, 12(1), pp. 433-459. 
FEC (2006), Total cost of ownership guidance, Federal Electronic Challenge, 15 March, viewed 10 Jun 2013 <https://www.greenbiz.com/sites/default/files/document/Cus tomO16C45F77406.pdf>.

Fel, F \& Griette, E 2017, Near-reshoring your supplies from China: a good deal for financial motives too, Strategic Direction, 33(2), pp. 24-26.

Fine, C 2013, Intelli-sourcing to replace offshoring and supply chain transparency increases, Journal of Supply Chain Management, vol. 49, pp. 6-7.

Fisher, ML 1997, What is the right supply chain for your product?, Harvard Business Review, 4(1), pp. 103-117.

Foerstl, K, Kirchoff, JF \& Bals, L 2016, Reshoring and insourcing: drivers and future research directions, International Journal of Physical Distribution \& Logistics Management, 46 (5), pp. 492-515.

Foss, NJ 1996, Research in strategy, economics, and Michael Porter, Journal of Management Studies, 33 (1), pp. 1-24.

Fratocchi, L, Di Mauro, C, Barbieri, P, Nassimbeni, G \& Z, A 2014 , When manufacturing moves back: concepts and questions, Journal of Purchasing and Supply Management, 20 (1), pp. 54-59.

Fratocchi, L, Vignoli, M \& Zanoni, A (2016), Motivations of manufacturing reshoring: an interpretative framework, International Journal of Physical Distribution \& Logistics Management, 46 (2), pp. 98-127.

Frohlich, M. T. and Westbrook, R. (2001), Arcs of integration: an international study of supply chain strategies, Journal of Operations Management, 19 (2), pp. 185-200.

Fynes, B., de BÚrca, S. and Voss, C. (2007). Supply chain relationship quality, the competitive environment and performance, International Journal of Production Research, 43(16), pp.3303-3320.

Garfamy, R. M. (2006), A data envelopment analysis approach based on total cost of ownership for supplier selection, Journal of Enterprise Information Management, 19(6), pp. 662-678.

Georgiadis, M.C., Tsiakis, P., Longinidis, P. and Sofioglou, M.K. (2011), Optimal design of supply chain networks under uncertain transient demand variations, Omega, 39(3), pp. 254-272.

Gyarmathy, A. (2018), Exploring Agile Supply Chains for Creating Innovative Products Closer to the End-user PhD Thesis, RMIT University, Melbourne, Australia

Gray, J. V., Roth, A. V. and Leiblein, M. J. (2011), Quality risk in offshore manufacturing: Evidence from the pharmaceutical industry, Journal of Operations Management, 29(7-8), pp. 737-752.

Gunasekaran, A., Lai, K. and Edwin Cheng, T.C. (2008), Responsive supply chain: A competitive strategy in a networked economy, Omega, 36(4), pp. 549-564.

Hagman, J., Ritzen, S., Janhager Stier, J. and Susilo, Y. (2016), Total cost of ownership and its potential implications for battery electric vehicle diffusion, Research in Transportation Business \& Management, 18(1) pp. 11-17.

Hartman, P. L., Ogden, J. A., Wirthlin, J. R. and Hazen, B. T. (2017), Nearshoring, reshoring, and insourcing: Moving beyond the total cost of ownership conversation, Business Horizons, 60(3), pp. 363-373.

Holweg, M., Reichhart, A. and Hong, E. (2011), On risk and cost in global sourcing, International Journal of Production Economics, 131(1), pp. 333-341.

Jia, F., Orzes, G., Sartor, M. and Nassimbeni, G. (2017), Global sourcing strategy and structure: towards a conceptual framework, International Journal of Operation and Production Management, 37(7), pp. 840-864.

Kara, S, Ibbotson, S and Kayis, B (2014), Sustainable product development in practice: an international survey, Journal of Manufacturing Technology Management, 25(6), pp. 848-872.
Kazmer, D.O. (2014), Manufacturing outsourcing, onshoring, and global equilibrium, Business Horizons, 57(4), pp. 463-472.

Lambert, D.M. and Cooper, M.C. (2000), Issues in supply chain management, Industrial Marketing Management, 29(1), pp. 65-83.

Lau, H.C.W. and Lee, W.B. (2000), On a responsive supply chain information system, International Journal of Physical Distribution \& Logistics Management, 30(7/8), pp. 598-610.

Learned, E.P., Christensen, C.R., Andrews, K.P. and Guth, W.D. (1969), Business Policy: Text and Cases, Homewood, IL: Irwin, US.

Lee, H., Padmanabhan, V. and Whang, S. (1997), Information Distortion in a Supply Chain: The Bullwhip Effect, Management Science, 43(4), pp. 546-558.

Leonard-Barton, D. (1992), Core capabilities and core rigidities: a paradox in managing new product development, Strategic Management Jorunal, 13(1), pp. 111-125.

Liao Y., Hong, P., and Subba Rao, S. (2010) Supply management, supply flexibility and performance outcomes: an empirical investigation of manufacturing firms, Journal of Supply Chain Management, 43 (1), pp. 6-22.

Liu, S., Lin, J. and Hayes, A. K. (2010), An agile and diversified supply chain: reducing operational risks, Competitiveness Review: An International Business Journal incorporating Journal of Global Competitiveness, 20 (3), pp. 222-234.

Lo, S.M. and Power, D. (2010), An empirical investigation of the relationship between product nature and supply chain strategy, Supply Chain Management, 15 (2), pp. 139-153.

Malakouti, M, Reaei, S. and Kalantari Shahijan, M. (2017), Agile supply chain management (ASCM): a management decisionmaking approach, Asia Pacific Journal of Marketing and Logistics, 29(1), pp. 171-182.

March, J. G. (1991), Exploration and exploitation in organizational learning, Organization Science, 2(1), No. pp. 71-87.

Markides, C. and Berg, N. (1988), Manufacturing Offshore Is Bad Business, Harvard Business Review. Available at: https://hbr.org/1988/09/manufacturing-offshore-is-badbusiness.

Mentzer, J.T. (1997), Validity in logistics research, Journal of Business Logistics, 18(1), pp. 199-216.

Mcivor, R. (2009), How the transaction cost and resource-based theories of the firm inform outsourcing evaluation, Journal of Operations Management, 27(1), No. 1, pp. 45-63.

Mohamud, M. and Sarpong, D. (2016), Dynamic capabilities: towards an organizing framework, Journal of Strategy and Management, 9(4), pp. 511-526.

Moradlou, H., Backhouse, D., Ranganathan, R., (2017) Responsiveness, the primary reason behind re-shoring manufacturing activities to the UK: An Indian industry perspective, International Journal of Physical Distribution \& Logistics Management, 47(2/3), pp. 222-236

Mora-Monge, C., Quesada, G., Marvin E., Davis, J.M. (2019) Trust, power and supply chain integration in Web-enabled supply chains, Supply Chain Management, 24(4), pp. 524-539.

Moser, H. (2011), Total cost of ownership calculation, Fastener Technology International, 34(4), pp. 54.

Mudalige, D., Ismail, N.A. amd Malek, M.A. (2019), Exploring the Role of Individual Level and Firm Level Dynamic Capabilities in SMEs' Internationalization, Journal of International Enterpreneurship, 17(1), pp. 41-74

Oshri, I., Kotlarsky, J., Rottman, W.J. and Willcocks, L.L. (2009), Global sourcing: recent trends and issues, Information Technology \& People, 22(3) pp. 192-200.

Pagani, R. (2004), Manufacturing execs should focus on becoming lean before going offshore. Financial Times.

Parente, R. C., Baack, D. W. and Hahn, E. D. (2011), The effect of supply chain integration, modular production, and cultural distance on new product development: A dynamic capabilities approach, Journal of International Management, 17(4), pp. 278-290. 
Pettus, M. L., Kor, Y. Y. and Mahoney, J. T. (2009), A theory of change in turbulent environments: the sequencing of dynamic capabilities following industry deregulation, International Journal of Strategic Change Management, 1(3), pp. 186-211.

Pezeshkan, A., Fainshmidt, S., Nair, A., Frazier, M. and Markowski, E. (2015), An empirical assessment of the dynamic capabilities-performance relationship Journal of Business Research 69(8). pp. 2950-2956

Picker, I, (2016), Manufacturing in America: The Real Benefits and the Drawbacks or Reshoring, CGS blog, 6 July, viewed 18 September 2016 , <https://www.cgsinc.com/blog/manufacturing-americabenefits-and-drawbacks-reshoring >

Platt, K. W. and Song, N. (2010), Overseas sourcing decisions - the total cost of sourcing from China, Supply Chain Management: An International Journal, 15(4), pp. 320-331.

Porter, M. E. (1979), How competitive forces shape strategy, Harvard Business Review, 57(2), pp. 137-145.

Porter, M. E. (1998), On Competition, USA, Harvard Business School Press.

Porter, M. E. (2008), Competitive Advantage, Riverside: Free Press.

Porter, M. E. 2008. Competitive Advantage: Creating and Sustaining Superior Performance, Simon \& Schuster, New York.

Radjou, N. (2000), Deconstruction of the suply chain, Supply Chain Management Review, 4(5)

Ritter, R.C. and Sternfels, R.A. (2004), When offshore manufacturing doesn't make sense, McKinsey Quarterly: Wall Street Journal, viewed 19 September 2016, http://www.metalsealprecision.com/images/pdfs/G_When_o ffshoring_doesnt_make_sense.pdf, pp. 124-127.

Rojo, A., Stevenson, M., Llorens M., Francisco J and PerezArostegui, M.N. (2018) Supply chain flexibility in dynamic environments, International Journal of Operations \& Production Management 38(3), pp. 636-666.

Saccani, N., Perona, M. and Bacchetti, A. (2017), The total cost of ownership of durable consumer goods: A conceptual model and an empirical application, International Journal of Production Economics, 183(A), pp. 1-13.

Sarder, M.D., Miller, C. \& Ziaul, A. 2014, Understanding the reshoring decision-making process using AHP approach, paper presented at Industrial and Systems Engineering Research Conference. 2672-2681

Selznick, P. (1957), Leadership in Administration: a Sociological Interpretation, University of California Press, Harper \& Row, London.

Simchi-Levi, D. (2005), Designing and managing the supply chain, Mcgraw-Hill College.

Singh, R, Koul, S \& Kumar, P (2017), Analysing the interaction of factors for flexibility in supply chains, Journal of Modelling in Management, 12(4)pp. 671-689.

Sirmon, D. G., Hitt, M. A., Arregle, J.-L. and Campbell Tochman, J. (2010), The dynamic interplay of capability strengths and weaknesses: investigating the bases of temporary competitive advantage, Strategic Management Journal, 31(13), pp. 13861409.

Sharma, S (2010), Supply chain management-concept, practices, and implementation, Oxford University Press, India

Smith, K. and Grimm, C. (1987), Environmental variation, strategic change and firm performance: A study of railroad deregulation, Strategic Management Journal, 8(4), pp. 363376.

Stanczyk, A., Cataldo, Z., Blome, C. and Busse, C. (2017), The dark side of global sourcing: a systematic literature review and research agenda, International Journal of Physical Distribution \& Logistics Management, 47(1), pp. 41-67.

Stanford, J. (2016). The Australia Institute, Tai.org.au. Available at: http://www.tai.org.au/sites/default/files/Manufacturing\%20B riefing $\% 20$ Paper\%20FINAL.pdf
Stavrulaki, E \& Davis, M (2010), Aligning products with supply chain processes and strategy, The International Journal of Logistics Management, 21(1), pp. 127-151.

TAI (2016), Manufacturing (still) matters, Centre for Future Work at the Australia Institute, 2 June, Canberra, viewed 28 May 2017 , http://www.futurework.org.au/manufacturing_still_matters

Tarafdar, S.Q.M. (2013), Lean and agile supply chain strategies and supply chain responsiveness: the role of strategic supplier partnership and postponement, Supply Chain Management, 18(6), pp. 571-582.

Teece, D. (2007), Explicating dynamic capabilities: the nature and microfoundations of (sustainable) enterprise performance, Strategic Management Journal, 28(13), pp. 1319-1350.

Teece, D. J., Pisano, G. and Amy, S. (1997), Dynamic Capabilities and Strategic Management, Strategic Management Journal, 18(7) pp. 509-533.

Tiwana, A. and Bush, A. A. (2007), A comparison of transaction cost, agency, and knowledge-based predictors of IT outsourcing decisions: A U.S.-Japan cross-cultural field study, Journal of Management Information System, 24(1), pp. 259300.

Trauth, E. (2001), The Choice of Qualitative Methods in IS Research, Qualitative Research in IS, pp.1-19

Turner, N., Aitken, J., Bozarth C. (2018), A framework for understanding managerial responses to supply chain complexity, International Journal of Operations \& Production Management, 38(6)pp. 1433-1466.

Vos, F. G. S., Scheffler, P., Schiele, H. and Horn, P. (2016), Does global sourcing pay-off? A competitive dynamics perspective, Journal of Purchasing and Supply Management, 22(4), pp. 338-350.

Walsham, G. (1995), Interpretive case studies in IS research: nature and method, European Journal of Information Systems, 4(2), pp.74-81.

Wang, C. L. and Ahmed, P. K. (2007), Dynamic Capabilities: A Review and Research Agenda, The International Journal of Management Reviews, Vol. 9, No. 1, pp. 31-51.

Weber, M., Hiete, M., Lauer, L. and Rentz, O. (2010), Low cost country sourcing and its effects on the total cost of ownership structure for medical devices manufacturer, Journal of Purchasing and Supply Management, 16(1), pp. 4-16.

Webster, J. and Watson, R. (2002), Analyzing the Past to Prepare for the Future: Writing a Literature Review, [online] 26(2,) pp. xiii-xxiii.

Wernerfelt, B. (1984), A Resource-Based View of the Firm, Strategic Management Journal, Vol. 5(2), pp. 171-180.

Wiesmann, B., Snoei, J.R., Hilletofth, P., Eriksson, D. (2017) Drivers and barriers to reshoring: a literature review on offshoring in reverse, European Business Review, 29(1), pp.15-42,

William, Y.C. (2009), International sourcing: offshore or nearshore?, World Trade, 22(1), pp. 46.

Williamson, O.E. (1975), Market and hierarchies: analysis and antitrust implications, The Free Press, New York.

Yin, R.K. (2003), Case study research: design and methods, Sage, Thousand Oaks, CA.

Young, L. W. (2006), A Novel framework for evaluating internetenabled value delivery business models, $\mathrm{PhD}$, The University of Melbourne.

Yusuf, Y.Y., Sarhadi, M. \& Gunasekaran, A. (1999), Agile manufacturing: the drivers, concepts and attributes, International Journal of Production Economics, 62(1-2), pp. $33-43$.

Zachariassen, F. and Arlbjorn, J. S. (2011), Exploring a differentiated approach to total cost of ownership, Industrial Management \& Data Systems, 111(3), pp. 448-469.

Zahra, S. A., Sapienza, H. J. and Davidsson, P. (2006), Entrepreneurship and Dynamic Capabilities: A Review, 
Model and Research Agenda, Journal of Management Studies, 43(4), pp. 917-955.
Zollo, M. and Winter, S.G. (2002), Deliberate learning and the evolution of dynamic capabilities, Organization Science, 13(3), pp. 339-351.

Dr Andrea Gyarmathy Andrea Gyarmathy is an Operation and Supply Chain Management professional and business academic of the 21st century. Andrea completed her Ph.D. at RMIT University, Australia. Her research interests lie in the area of agile and responsive supply chain management, as well as onshore manufacturing, dynamic capabilities and total cost of ownership evaluation, ranging from theory to design to implementation. Recently she is a Lecturer and MBA dissertation/RM Lead at Glasgow Caledonian University. She is actively collaborating with researchers in several other disciplines of operation, supply chain management, and Industry 4.0.

Dr Konrad Peszynski is a Senior Lecturer in the College of Business at RMIT University. Dr Peszynski's research focuses on higher degree by research, strategy and policy, the social aspects of information, the relationship of culture to information and supply chain management. His recent work explores the impact of the fourth industrial revolution and the changing curriculum, the role of supervision, as well as innovative higher degree by research experiences.

Dr Leslie Young is an Academic in the College of Business at RMIT University. Dr Young's research has centred mostly in the area of strategic use of information systems and cloud computing. His current research interest is exploring how ICT can be used effectively for developing countries, especially for the people groups that are marginalised. 